\title{
Small molecule kinase inhibitor LRRK2-IN-1 demonstrates potent activity against colorectal and pancreatic cancer through inhibition of doublecortin-like kinase 1
}

\author{
Nathaniel Weygant ${ }^{1 \dagger}$, Dongfeng Qu ${ }^{1,2+}$, William L Berry ${ }^{3,4}$, Randal May ${ }^{1,2}$, Parthasarathy Chandrakesan ${ }^{1}$, \\ Daniel B Owen ${ }^{1}$, Sripathi M Sureban ${ }^{1,2}$, Naushad Ali ${ }^{1,2,3}$, Ralf Janknecht ${ }^{3,4}$ and Courtney W Houchen ${ }^{1,2,3,5^{*}}$
}

\begin{abstract}
Background: Doublecortin-like kinase 1 (DCLK1) is emerging as a tumor specific stem cell marker in colorectal and pancreatic cancer. Previous in vitro and in vivo studies have demonstrated the therapeutic effects of inhibiting DCLK1 with small interfering RNA (siRNA) as well as genetically targeting the DCLK1 ${ }^{+}$cell for deletion. However, the effects of inhibiting DCLK1 kinase activity have not been studied directly. Therefore, we assessed the effects of inhibiting DCLK1 kinase activity using the novel small molecule kinase inhibitor, LRRK2-IN-1, which demonstrates significant affinity for DCLK1.

Results: Here we report that LRRK2-IN-1 demonstrates potent anti-cancer activity including inhibition of cancer cell proliferation, migration, and invasion as well as induction of apoptosis and cell cycle arrest. Additionally we found that it regulates stemness, epithelial-mesenchymal transition, and oncogenic targets on the molecular level. Moreover, we show that LRRK2-IN-1 suppresses DCLK1 kinase activity and downstream DCLK1 effector C-MYC, and demonstrate that DCLK1 kinase activity is a significant factor in resistance to LRRK2-IN-1.

Conclusions: Given DCLK1's tumor stem cell marker status, a strong understanding of its biological role and interactions in gastrointestinal tumors may lead to discoveries that improve patient outcomes. The results of this study suggest that small molecule inhibitors of DCLK1 kinase should be further investigated as they may hold promise as anti-tumor stem cell drugs.
\end{abstract}

Keywords: DCLK1, LRRK2-IN-1, Tumor stem cell, Small-molecule inhibitor, Kinase inhibitor

\section{Background}

Small-molecule kinase inhibitors hold significant promise in extending lifespan and improving outcomes for cancer patients. Imatinib (Gleevec ${ }^{\circ}$ ), an inhibitor designed to target the BCR-ABL fusion complex in chronic myelogenous leukemia $(\mathrm{CML})$, was the first successful drug in this category and exemplifies the therapeutic potential of these drugs. With this therapy CML has been transformed from an often-fatal malignancy to a manageable condition with

\footnotetext{
* Correspondence: courtney-houchen@ouhsc.edu

${ }^{\dagger}$ Equal contributors

'Department of Medicine, University of Oklahoma Health Sciences Center, Oklahoma City, OK, USA

${ }^{2}$ Department of Veterans Affairs Medical Center, Oklahoma City, OK, USA

Full list of author information is available at the end of the article
}

survival rates similar to the disease-free population [1]. In solid tumor cancers, many kinase inhibitors such as sorafenib and gefitinib have been shown to extend the overall and progression-free survival of patients [2,3]. However, only a very small portion of the human kinome has been targeted with inhibitors at the phase I clinical trial level [4] and although many kinase inhibitors are currently in various phases of clinical trials for different cancers, there is a need for new inhibitors targeting novel kinases implicated in tumorigenesis, recurrence, and metastasis.

Doublecortin-like kinase 1 (DCLK1) is a microtubulebinding member of the calmodulin-dependent kinase 
family and has been identified as a tuft cell marker with stem-like properties in the small intestine and pancreas [5-10]. DCLK1 is overexpressed in tumors and pancreatic intraepithelial (PanIN) lesions of P48 ${ }^{\mathrm{Cre}} \mathrm{Kras}^{\text {LSLG12D }}$ $\mathrm{Pdx} 1^{\text {Cre }}$; Kras ${ }^{\text {LSLG12D }}, \mathrm{Pdx} 1^{\text {Cre }}$; Kras ${ }^{\text {LSLG12D }}$; Tp53 ${ }^{\text {Flox/+ }}$ and Mist1 ${ }^{\text {CreER }}$; Kras ${ }^{\text {LSLG12D }}$ pancreatic cancer mice as well as surgical resection specimens of human pancreatic ductal adenocarcinoma (PDAC) patients, and is significantly correlated to PanIN lesion stage $[8,9]$. DCLK1 is also overexpressed in the Apc ${ }^{\mathrm{min} /+}$ mouse model of intestinal neoplasia and surgical specimens of human colon cancer [5,7]. Recently, cutting-edge studies using the Dclk1 ${ }^{\text {CreERT2 }}$; Apc ${ }^{\text {min/+ }}$ lineage tracing mouse model have demonstrated that Dclk $1^{+}$cells selectively mark tumor stem cells (TSCs) in intestinal adenomas and diphtheria-toxin inducible ablation of these cells results in massive loss of polyps with no apparent negative effects on the normal intestine [11]. Moreover, a recent study demonstrated that a unique population of $\mathrm{DCLK} 1^{+}$stemlike cells is capable of initiating pancreatic tumorigenesis [9]. These data provide a basis for DCLK1 targeted therapies.

DCLK1 has been targeted on the genetic level in some cancers with promising results. siRNA-mediated silencing of DCLK1 triggers apoptosis in SHSY5Y neuroblastoma cells [12]. Moreover, a recent study demonstrated that doxycycline-inducible knockdown of DCLK1 inhibits proliferation, mitochondrial activity, and ATP synthesis in N1E-115 neuroblastoma cells and delays progression of N1E-115 tumor xenografts [13]. Therapeutic targeting of DCLK1 in gastrointestinal cancer is highly desirable because of its expansion in tumors and tumor stem cell status. siRNA-mediated knockdown of DCLK1 in the AsPC-1 pancreatic cancer cell line results in inhibition of epithelial-to-mesenchymal transition (EMT) and oncogenic targets through induction of tumor suppressor miRNAs let-7a and miR-144 and EMT-inhibitor miR-200a [8]. In HCT116 (colon) and AsPC-1 (pancreatic) tumor xenografts, DCLK1 siRNA nanoparticle treatment significantly reduces tumor growth and inhibits pluripotency and angiogenic factors without any indication of toxicity $[14,15]$. Despite these compelling findings, the effect of inhibiting DCLK1 kinase activity has not been investigated in cancer. Recently, the Gray group developed a kinase inhibitor targeting Leucinerich repeat kinase 2 (LRRK2), which is implicated in both genetically predisposed and sporadic Parkinson's disease [16]. This compound, LRRK2-IN-1, displayed significant and relatively selective affinity for DCLK1 $\left(K_{d}=5 \mathrm{nM}\right)$, compared to a $K_{d}$ of $20 \mathrm{nM}$ for LRRK2 [17]. Here we demonstrate that LRRK2-IN-1 elicits anticancer activity in part through inhibition of DCLK1, suggesting that DCLK1 kinase may be a promising anticancer target.

\section{Results}

\section{LRRK2-IN-1 inhibits DCLK1 kinase activity}

Kinome profiling suggests that LRRK2-IN-1 (Figure 1A) inhibits DCLK1 kinase with a dissociation constant of 5 $\mathrm{nM}$ [17]. In order to confirm this inhibition we performed an in vitro kinase assay using commercially available purified DCLK1 protein and autocamtide2 substrate with low concentration ATP $(1 \mu \mathrm{M})$. Remaining ATP following the reaction was quantified using luminescent kinase-glo ${ }^{\circledR}$ reagents which provides an inverse measure of kinase activity. Using this assay we estimated the $\mathrm{IC}_{50}$ of LRRK2-IN-1 inhibition of DCLK1 to be $2.61 \mathrm{nM}$ (Figure 1B), supporting the previously reported kinome profiling results [17]. To assess the inhibition of DCLK1 phosphorylation in vitro, AsPC-1 cells were treated with LRRK2-in-1 for 48 h. Phospho-DCLK1 (Ser30/336) was decreased in both 52 and $82 \mathrm{kDa}$ isoforms (long- $\beta / \alpha$ respectively) with LRRK2-IN-1 treatment in a dosedependent manner. Quantification of the ratio of phosphoDCLK1/DCLK1 revealed that the 52 and $82 \mathrm{kDa}$ isoforms decreased approximately $30 \%$ and $12.5 \%$ respectively following $5 \mu \mathrm{M}$ LRRK2-in-1 treatment ( $<$ 0.046; Figure 1C).

\section{LRRK2-IN-1 is an ATP-competitive inhibitor of DCLK1 kinase}

Following confirmation of LRRK2-IN-1's inhibitory activity against DCLK1 kinase, in silico molecular modeling and docking was conducted to determine the mechanism and localization of inhibition. Because the full crystal structure of DCLK1 has not been determined, homology models were constructed for DCLK1 isoform 2 (DCLK-long- $\alpha$ ) and 4 (DCLK-long- $\beta$ ). The protein kinase domain is a highly conserved structural feature of all kinases and DCLK1 is a member of the calmodulindependent protein kinase (CAMK) family, which has many structures solved (Additional file 1: Figure S1A). Therefore, these models are expected to be reasonably accurate. Both Sparks ${ }^{\mathrm{X}}$ Fold Recognition and SwissModel generated similar homology models of DCLK1 with a root mean square deviation (RMSD) of $0.89 \AA$, while the RMSD in the kinase domains of the long form models was $0.37 \AA$ A. Docking simulations were conducted using PatchDock and the homology model of DCLKlong- $\beta, 81 \%$ of which encompasses the protein kinase domain shared by all DCLK1 isoforms (Figure 1D). In the kinase domain, the highest ranked docking site for LRRK2-IN-1 was located directly within the ATPbinding pocket with close proximity to the kinase hinge and interacting residues located in the catalytic loop, activation loop, glycine-rich loop (P-loop), and $\alpha \mathrm{C}$-helix and including the highly conserved, catalytic site lysine 112/419 (Figure 1E; Additional file 1: Figure S2A). These results suggest that LRRK2-IN-1 inhibits DCLK1 kinase activity by competing with ATP for the binding pocket. 


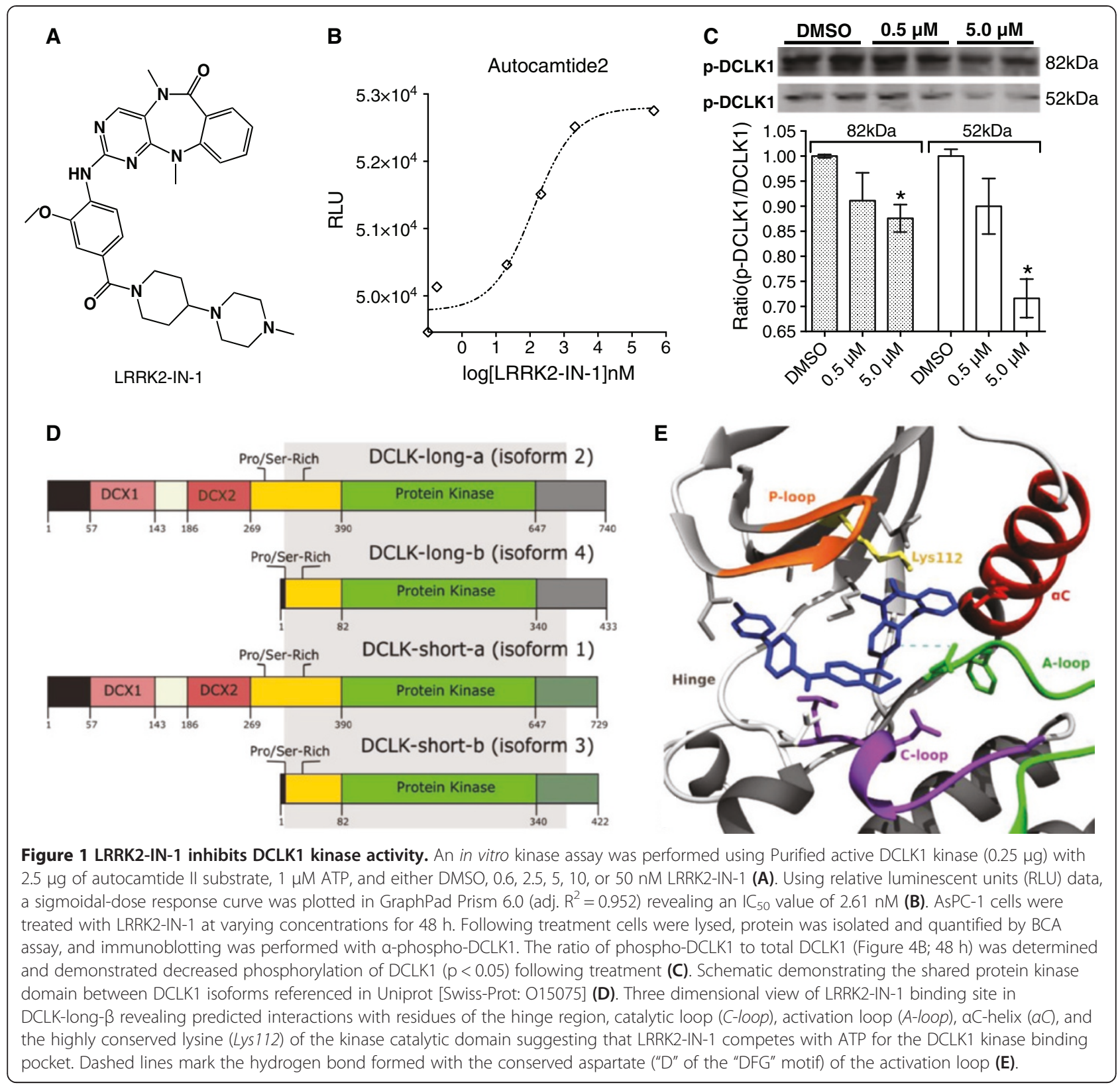

LRRK2-IN-1 inhibits proliferation, migration, and induces cell death with hallmarks of apoptosis

DCLK1 is overexpressed or demonstrates strong expression in many colon and pancreatic cancer cell lines (Additional file 1: Figure S2C) [18,19]. To assess the functional effects of LRRK2-IN-1 in vitro we chose to focus on the AsPC-1 human pancreatic cancer and HCT116 human colon cancer cell lines, which are both well characterized for their DCLK1 expression in the literature [7,9,14,15,20-22]. Both AsPC-1 and HCT116 cells were treated with various concentrations of LRRK2-IN-1 for $48 \mathrm{~h}$ and MTT proliferation assays were conducted. A significant dose-dependent reduction of cell proliferation was observed in the highly proliferative HCT116 colon cancer cell line (Figure 2A) and the AsPC-1 pancreatic cancer cell line (Figure 2B). Fitting a sigmoidal-dose response curve revealed $\mathrm{IC}_{50}$ values of 1.69 and $1.73 \mu \mathrm{M}$ for AsPC-1 $\left(R^{2}=0.79\right)$ and HCT116 $\left(R^{2}=0.94\right)$ cell lines respectively. Moreover, this anti-proliferative activity was observed in DLD-1 and HT-29 colon cancer cells and MiaPaCa-2 and SW1990 pancreatic cancer cells. Notably, SW1990 cells, which express high levels of DCLK1 (Additional file 1: Figure S2C), displayed resistance to LRRK2-IN-1 compared to the other lines with an $\mathrm{IC}_{50}$ of $>5 \mu \mathrm{M}$ (Additional file 1: Figure S1B). Furthermore, LRRK2-IN-1 was found to have cytotoxic effects in the 


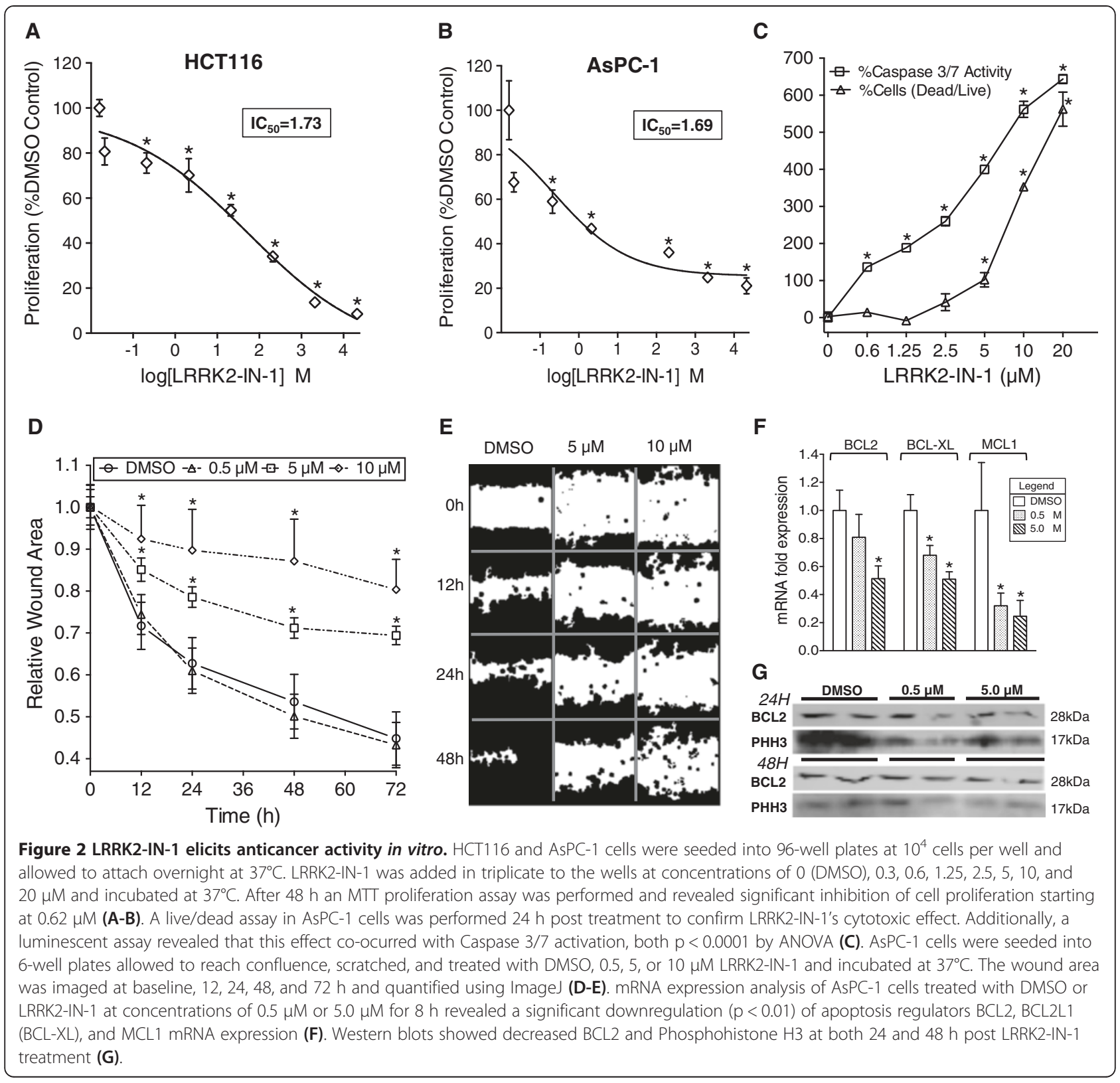

AsPC-1 cell line by live/dead viability assay $24 \mathrm{~h}$ post treatment (Figure 2C; Additional file 1: Figure S2B), and cells at this time point demonstrated significant dosedependent increases in caspase-3/7 activity (Figure 2C), which was exponentially associated $\left(R^{2}=0.98\right)$ with loss of cell viability (Additional file 1: Figure S2D). Moreover, LRRK2-IN-1 inhibited AsPC-1 migration at 5 and $10 \mu \mathrm{M}$ starting after $12 \mathrm{~h}$ treatment (Figure 2D-E). Relative to the original wound area, the average wound area was approximately $45 \% 72 \mathrm{~h}$ post DMSO treatment, but was approximately $70 \%$ and $80 \%$ at this time point for 5 and $10 \mu \mathrm{M}$ LRRK2-in-1 treatment respectively. This anti-migratory effect was highly dose dependent ( $\mathrm{p}<0.0001$ by ANOVA). Additionally, gene expression levels of apoptosis pathway inhibitors, BCL2L1 (BCL-XL), BCL2, and MCL1, were significantly decreased in AsPC-1 cells treated with LRRK2IN-1 for $8 \mathrm{~h}$ (Figure 2F). In confirmation of LRRK2-IN-1's anti-proliferative and pro-apoptotic properties, mitotic marker phosphohistone $\mathrm{H} 3$ and anti-apoptotic marker BCL2 protein levels were inhibited 24 and $48 \mathrm{~h}$ post treatment in these cells (Figure 2G).

\section{LRRK2-IN-1 induces G1 and G2/M cell cycle arrest}

AsPC-1 cells were treated with LRRK2-IN-1 for 24 and $48 \mathrm{~h}$. Cell cycle analyses were performed and revealed that LRRK2-IN-1 induces G1 arrest at low doses $(5 \mu \mathrm{M})$ and $\mathrm{G} 2 / \mathrm{M}$ arrest at high doses $(20 \mu \mathrm{M})$ at both time points (Figure $3 \mathrm{C}$ ). Moreover, G2/M arrest was strongly 


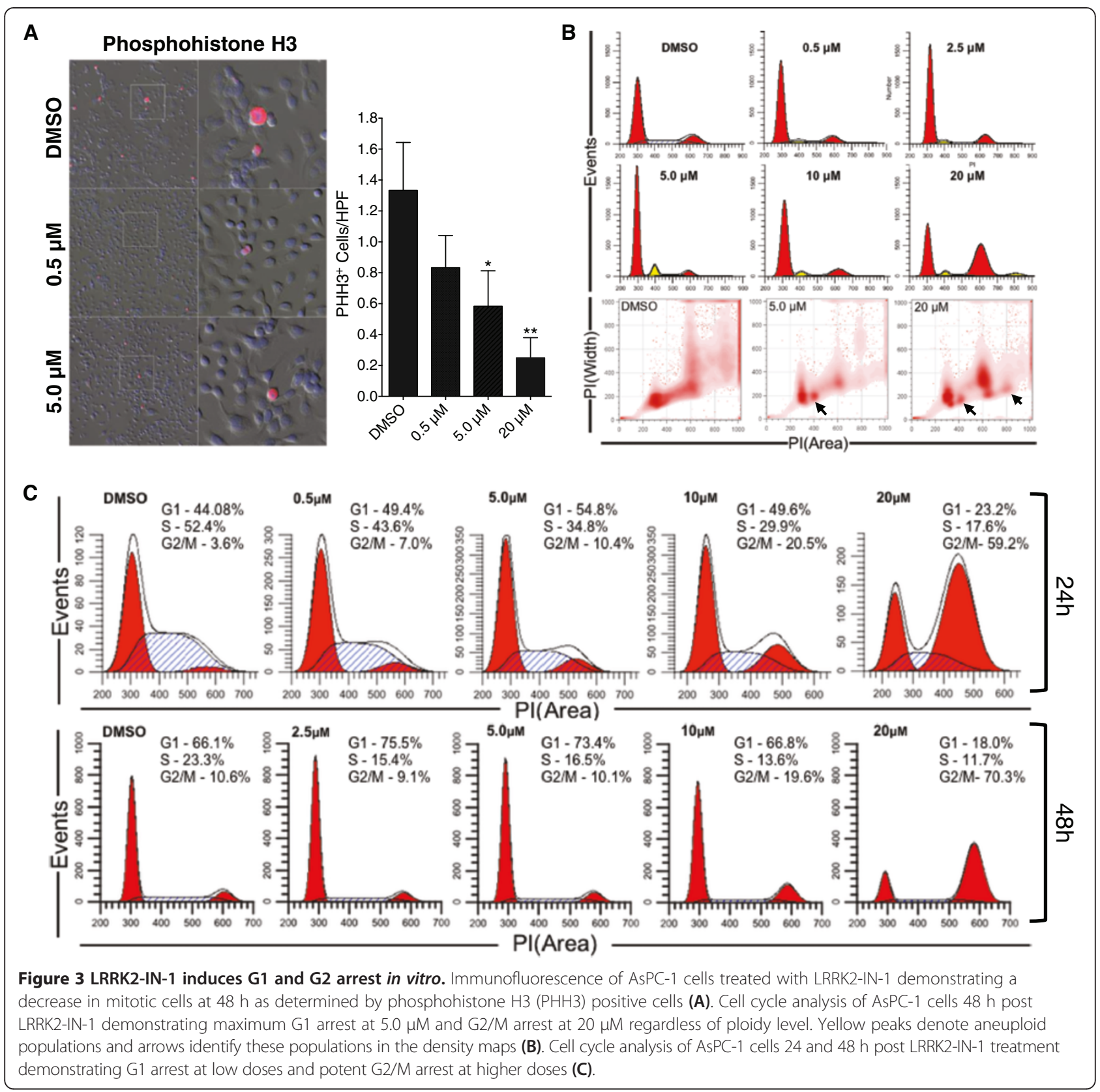

correlated to loss of cell viability at $24 \mathrm{~h}$ (Additional file 1: Figure S2E). Aneuploidy is well known to contribute to drug resistance [23]. LRRK2-IN-1 also induced G1 and $\mathrm{G} 2 / \mathrm{M}$ arrest in aneuploid AsPC-1 cells as demonstrated by PI analysis (Figure 3B). The dose-dependent decrease in phosphohistone $\mathrm{H} 3$ expression ( $\mathrm{p}=0.013$ by ANOVA) following treatment suggests arrest of cells in G2 phase specifically at higher doses (Figures 3A \& 2G). These data demonstrate that LRRK2-IN-1 reduces cancer cell proliferation and viability by inducing both $\mathrm{G} 1$ and G2/ $\mathrm{M}$ arrest. Moreover, the divergent cell cycle status following low and high-dose LRRK2-IN-1 suggests that as drug concentration increases further inhibition of target kinase activity, inhibition of a greater number of kinases, or another downstream interaction causes cells to preferentially pool in G2/M phase.

\section{LRRK2-IN-1 inhibits DCLK1 mRNA and protein expression}

Following LRRK2-IN-1 treatment, DCLK1 mRNA levels were decreased in a time-dependent manner when treated with $5 \mu \mathrm{M}$ of LRRK2-IN-1 ( $\mathrm{p}=0.004$ by ANOVA), and in a dose-dependent manner when treated with various concentrations of LRRK2-IN- 1 for $8 \mathrm{~h}$ ( $\mathrm{p}<0.0001$ by ANOVA; Figure 4A). DCLK1 mRNA levels were consistently 


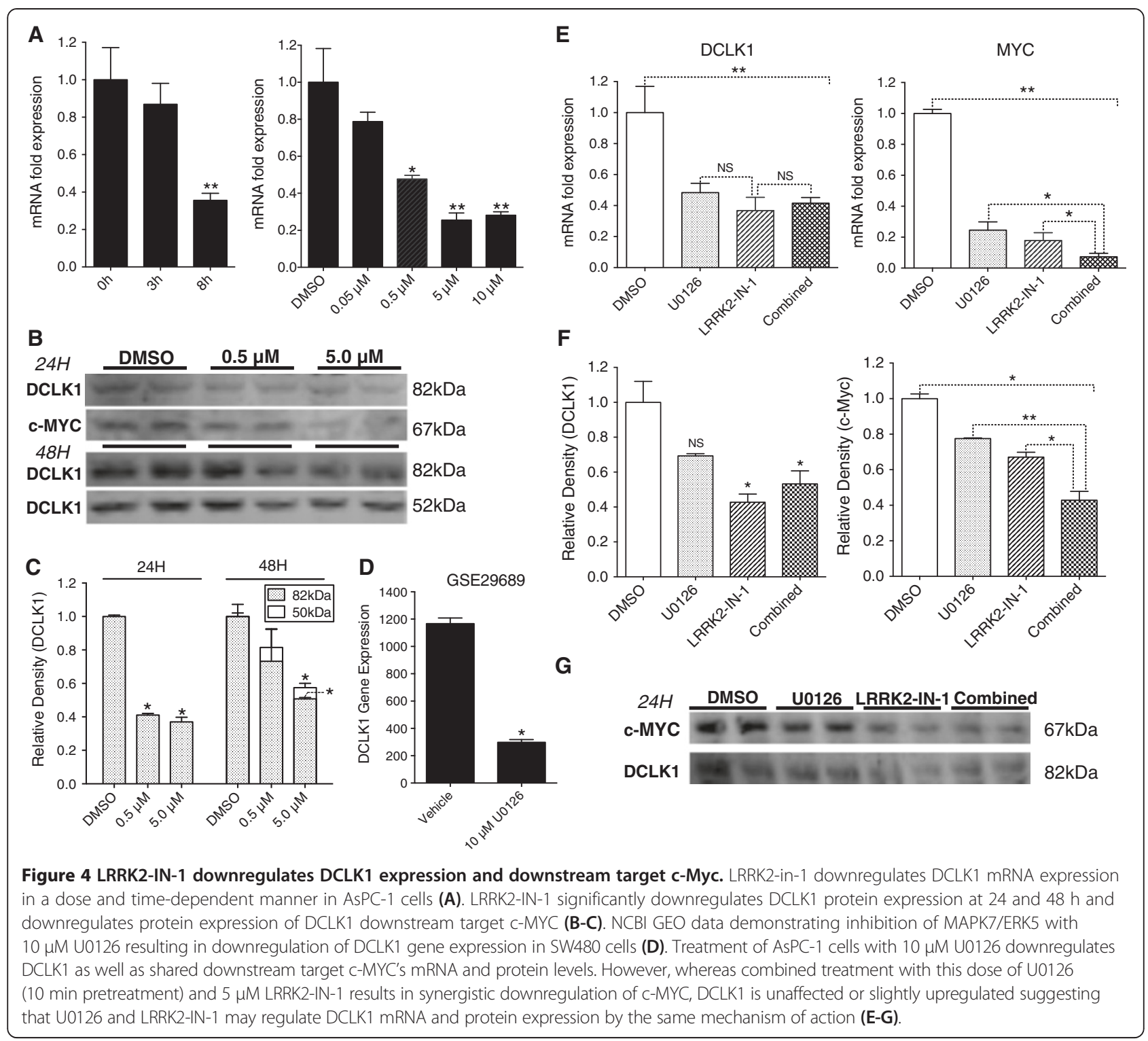

decreased approximately 65-75\% after $5 \mu \mathrm{M}$ LRRK2-IN-1 treatment for $8 \mathrm{~h}$. DCLK1 protein levels were also decreased in a dose-dependent manner, with an approximately $60 \%$ reduction for the $82 \mathrm{kDa}$ isoform at $24 \mathrm{~h}$, and a $45 \%$ reduction at $48 \mathrm{~h}$ following $5 \mu \mathrm{M}$ LRRK2-IN-1 treatment $(\mathrm{p}<0.03$; Figure 4B-C). Downstream target c-MYC protein expression was also downregulated $24 \mathrm{~h}$ following treatment (Figure 4B). We hypothesized that DCLK1 mRNA and protein expression is regulated through the inhibition of another target of LRRK2-IN-1. The MAPK/ERK signaling pathway is an important regulator of many cellular functions and modulates a wide range of molecular targets. MAPK7 (ERK5) is inhibited by LRRK2-IN-1 $\left(\mathrm{K}_{\mathrm{d}}=28 \mathrm{nM}\right)$ [17], so we investigated whether this may be a feasible driver of the observed downregulation of DCLK1 gene and protein expression. U0126 was developed as an inhibitor of MEK1/2 but has also been shown to inhibit MAPK7 [24]. Moreover, it was previously reported that U0126 suppresses upregulation of DCLK1 in response to NGF stimulation in PC12 cells [25] and a search of the NCBI gene expression omnibus database produced multiple datasets demonstrating significant DCLK1 downregulation following U0126 inhibition in colon cancer cell lines (Figure 4D \& Additional file 1: Figure S2F) $[26,27]$. As predicted, DCLK1 mRNA levels were decreased after $10 \mu \mathrm{M}$ U0126 treatment (Figure 4E). Ten minutes pretreatment of cells with this dose of U0126 followed by $5 \mu \mathrm{M}$ LRRK2-IN-1 treatment caused no further decrease in DCLK1 gene expression (Figure 4E). However, MYC, which is downstream of both DCLK1 
[8] and MAPK7 and encodes the c-MYC protein, was synergistically downregulated with combinatorial drug treatment compared to LRRK2-IN-1 or U0126 treatment alone ( $\mathrm{p}<0.005$; Figure $4 \mathrm{E})$. Highly similar results were also observed for protein expression of both DCLK1 and c-MYC $24 \mathrm{~h}$ post treatment $(\mathrm{p}<0.05$; Figure 4F-G). These results suggest that MAPK7 inhibition is a likely mechanism of action for DCLK1 downregulation by LRRK2-IN-1. Moreover, this data suggests that DCLK1 and the MEK1/2-MAPK7 cascade regulate c-MYC expression by complementary mechanisms.

\section{LRRK2-IN-1 reduces pluripotency and stem cell associated gene expression}

Stem and stem-like cells are characterized by the expression of specific transcription factors termed pluripotency factors. We have recently demonstrated that knockdown of DCLK1 decreases expression of these factors through regulation of miR-145 [15]. Expression levels of LIN28, NANOG, and SOX2 were significantly reduced after LRRK2-IN-1 treatment in AsPC-1 cells (Figure 5A). LGR5 and BMI1 are stem-cell markers coexpressed with DCLK1 in the intestine $[28,29]$, regulated downstream of DCLK1

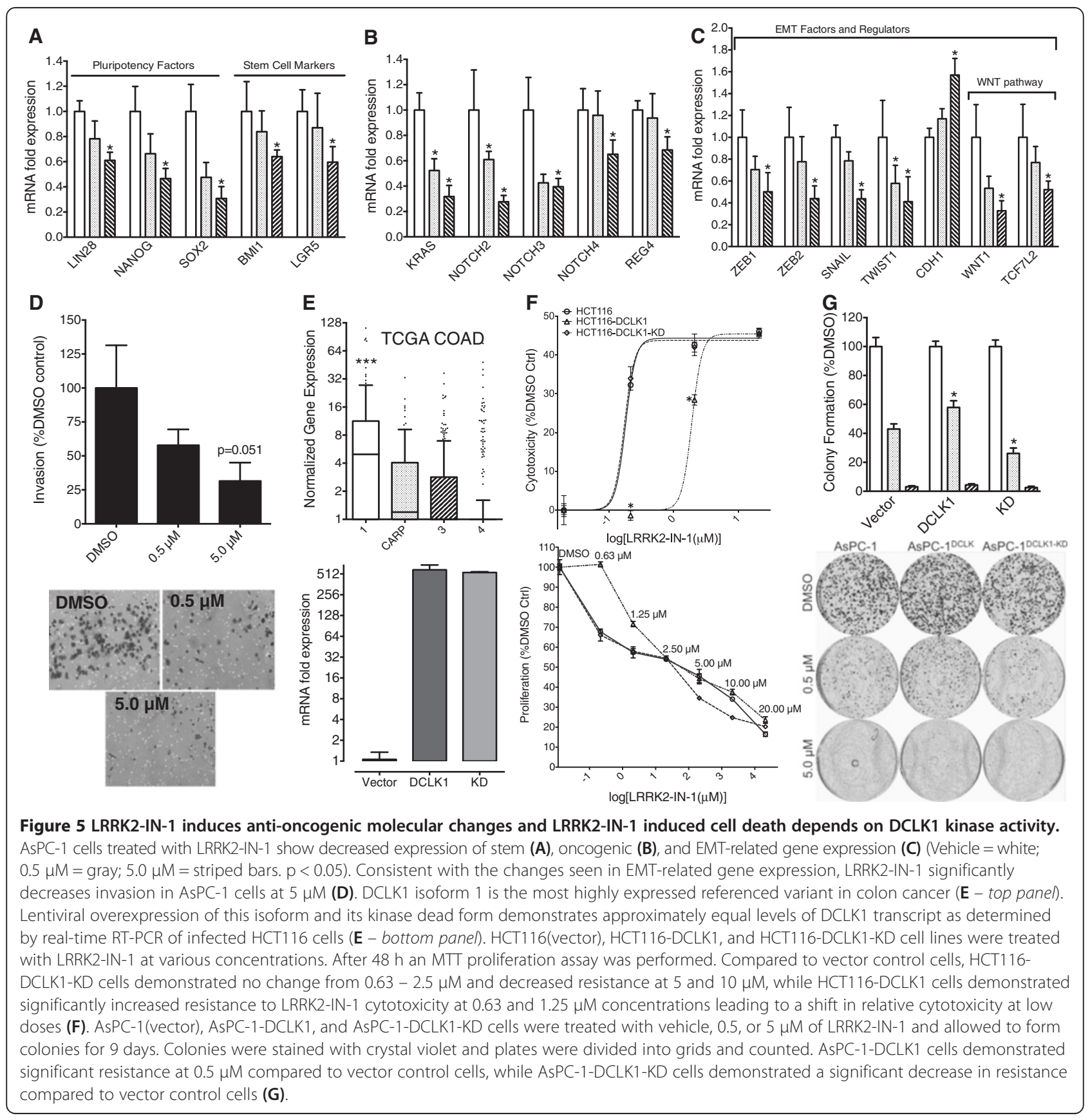


following radiation injury in intestinal epithelial DCLK1 knockout mice [30], and markers of populations of cells with tumor stem cell activity in intestinal adenomas [31] and pancreatic adenocarcinoma [32]. Both LGR5 and BMI1 mRNA expression levels were significantly downregulated following LRRK2-IN-1 treatment (Figure 5A). These results along with the c-MYC expression results demonstrate that LRRK2-IN-1 possesses anti-stemness properties.

\section{LRRK2-IN-1 inhibits oncogenic and EMT marker gene-expression}

Mutation of the KRAS oncogene is the primary initiator of PDAC and exerts its influence through multiple protumorigenic pathways [33]. These mutations are also present with high frequency in colorectal cancer and are correlated with poor overall survival [34]. LRRK2-IN-1 caused a significant downregulation of KRAS expression in AsPC-1 cells. Additionally, significant decreases were found in PDAC related genes $\mathrm{NOTCH} 2-4$ and REG4 (Figure 5B). However, there was no effect on NOTCH1 expression (data not shown).

At the time of diagnosis most PDAC patients present with metastatic disease [35]. Metastasis is driven by the process of EMT under the control of specific transcription factors, which allow newly transformed cancer cells to gain a stem-cell like phenotype [36]. LRRK2-IN-1 significantly upregulated epithelial marker E-cadherin (CDH1) while downregulating EMT factors SNAI1 (SNAIL), ZEB1, ZEB2, and TWIST1 mRNA expression (Figures 4C). The WNT pathway is heavily involved in regulating EMT primarily through nuclear $\beta$-catenin [37]. LRRK2-IN-1 downregulated the expression of WNT pathway genes WNT1, one of the upstream signaling proteins of the pathway, and TCF7L2/TCF4 (Figure 5C), an essential transcription factor which in complex with $\beta$-catenin directly regulates ZEB1 expression [38]. Consistent with the molecular changes seen in EMT related gene and protein expression there was a dose-dependent decrease in the invasive potential of AsPC-1 cells $24 \mathrm{~h}$ post LRRK2-IN-1 treatment, with an approximately $70 \%$ reduction in invasive potential following $5 \mu \mathrm{M}$ treatment (Figure 5D).

\section{DCLK1 promotes resistance to LRRK2-IN-1}

Analysis of RNA deep-sequencing data from the cancer genome atlas colon cancer dataset [39] revealed that DCLK1 transcript variant 1 , which encodes isoform 1 (also known as DCLK-short- $\alpha$ ), is the most highly expressed annotated variant (Figure 5E). To demonstrate that DCLK1 is a significant factor in LRRK2-IN-1's anticancer properties, both HCT116 and AsPC-1 cells were infected with Lentivirus containing the cDNA of DCLK1 isoform 1 or a kinase-dead mutant (K419R) of this isoform, which was previously shown to inactivate DCLK1's kinase activity [40-42]. DCLK1 mRNA expression levels were increased about 500 fold in both wild type DCLK1 and DCLK1-K419R overexpressing cells compared to vector infected cells (Figure 5E). DCLK1 has recently been reported to be a significant contributor to proliferation and mitochondrial activity in neuroblastoma cells [13]. We found that overexpression of DCLK1 resulted in significant resistance to LRRK2-IN-1's anti-proliferative effect in the highly proliferative HCT116 cell line up to $2.5 \mu \mathrm{M}(\mathrm{p}=0.03)$, whereas overexpression of DCLK1K419R was virtually identical to vector control at these doses (Figure 5F). To further characterize DCLK1-based resistance to LRRK2-IN-1 we performed a colony formation assay using AsPC-1 cells overexpressing DCLK1 and DCLK1-K419R. We observed a significant increase in colonies formed relative to vector control cells in cells overexpressing DCLK1 at $0.5 \mu \mathrm{M}(\mathrm{p}=0.035)$, while cells overexpressing DCLK1-K419R had fewer colonies at this concentration. $5 \mu \mathrm{M}$ LRRK2-IN-1 proved to be highly effective and colonies were virtually non-existent in all cell lines (Figure 5G). These results demonstrate that DCLK1 kinase activity confers resistance to LRRK2-IN-1.

\section{LRRK2-IN-1 inhibits the growth of pancreatic tumor xenografts}

To assess the effect of LRRK2-IN-1 in vivo, a tumor xenograft study ( $\mathrm{n}=4$ per group) was conducted. AsPC1 tumor xenografts were injected with LRRK2-IN-1. Peritumoral injection of the drug resulted in a significant decrease in tumor volume (Figure 6A). There was also a notable decrease in the excised volume and weight of tumors from LRRK2-IN-1 treated mice (Figure 6B-D). Both the mean excised tumor volume and weight decreased more than $50 \%$ following LRRK2-IN-1 treatment for 4 weeks. This data demonstrates that LRRK2-IN-1 is effective in vivo.

\section{Discussion}

The functional significance of DCLK1 in cancer has only been explored recently. Although siRNA-mediated knockdown of DCLK1 gene expression is antiproliferative and induces tumor growth arrest [7,11,13-15], the effect of inhibiting DCLK1 kinase activity in cancer had not been previously assessed. The findings presented here have potentially wide-ranging implications in the development of novel, targeted agents against DCLK1 and provide additional validation for DCLK1 as a therapeutic target. It is notable that some novel anti-cancer kinase inhibitors such as MAPK7 inhibitor XMD8-92, PLK1-inhibitor BI-2536, and ALK-inhibitor TAE-684 [43] demonstrate affinity for DCLK1 kinase that is comparable to their target kinases (http://lincs.hms.harvard. $\mathrm{edu} /$ ). This off-target inhibition may play a role in the therapeutic effects of these drugs. In fact, DCLK1 gene 


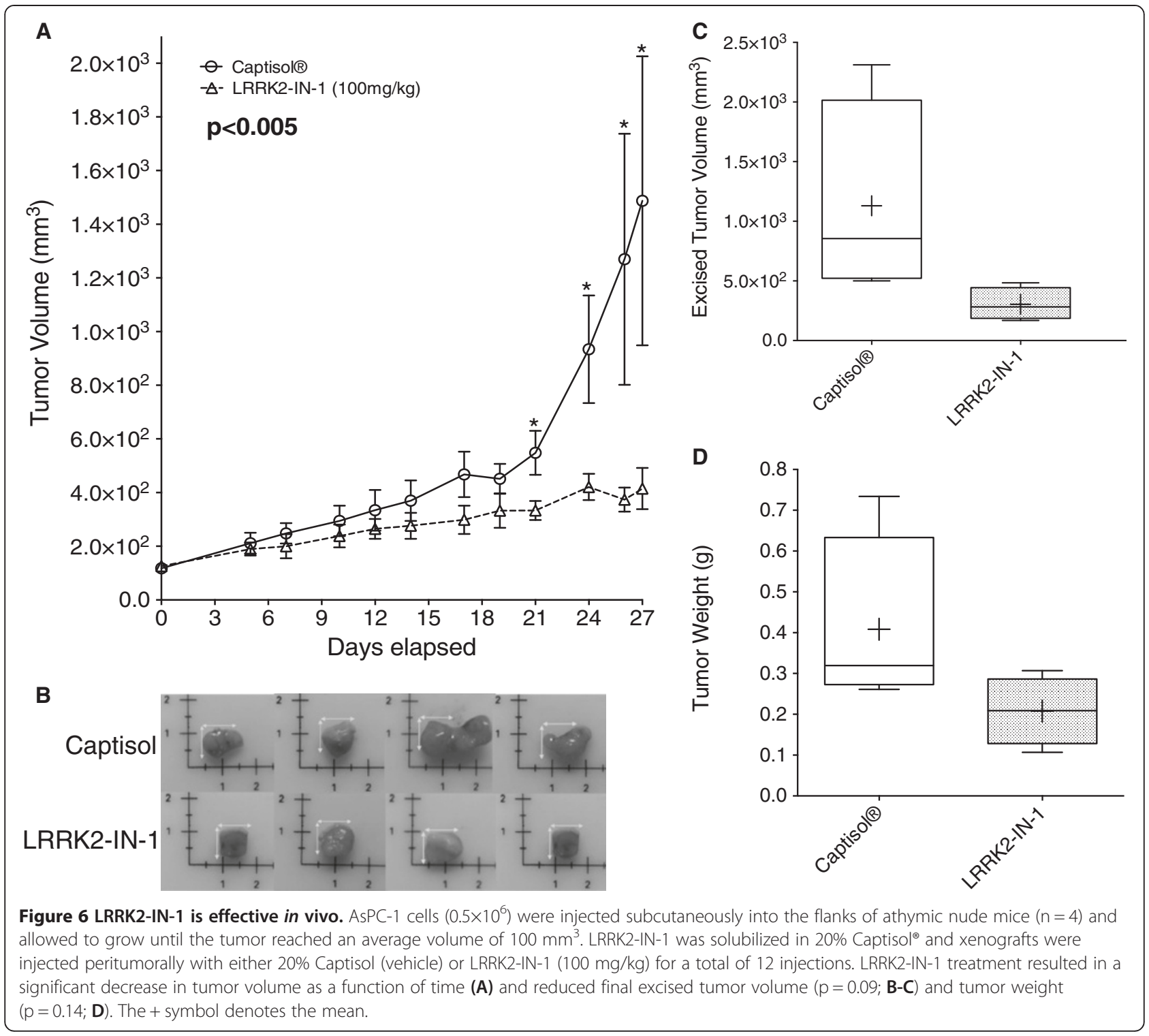

expression was highly upregulated in 2 out of 4 HCT116 cell clones that demonstrated resistance to BI-2536 [44]. The structural similarities between these inhibitors and others that have been synthesized and profiled may aid in the design of DCLK1 inhibitors with improved chemical characteristics and favorable delivery and safety profiles. Additionally, the results of our study suggest the possibility that DCLK1 kinase activity may be involved in regulating proliferation, cell cycle, EMT, and stemness pathways in cancer. However, before these hypotheses can be confirmed, it will be essential to carefully dissect the role of each domain in each of the 4 primary human DCLK1 isoforms in addition to the smaller peptide-like isoform of DCLK1 (CAMK-related peptide; "CARP").

The MAPK/ERK pathway regulates many functions essential to cancer cell survival and proliferation [45]. In these studies we used U0126 to demonstrate a link between MEK1/2 cascade inhibition and DCLK1 expression in human pancreatic cancer cells and confirmed our results with microarray data generated by other groups in treated colon cancer cell lines (Figure 4D \& Additional file 1: Figure S2F). Additionally, a previous paper demonstrated that nuclear translocation of phosphorylated DCLK1-short is attenuated in U0126-treated Xaenopus laevis melanotrope cells [46], which if broadly applicable, implies that MEK1/ 2 cascade inhibition has the potential to limit or prevent DCLK1-based intracellular signaling. The data from this study and our previous studies [7,8] suggest that DCLK1 interacts with and regulates the MAPK/ERK effector c-MYC. Interestingly, a large-scale protein-protein interaction study identified physical interaction between DCLK1 and c-MYC at DCLK1 amino acids 385-399 [47], 
located at the N-terminal end of DCLK1's kinase domain. If confirmed, this would suggest that targeting DCLK1 regulates MYC through post-translational modification, which could also explain the synergistic effect of combinatorial LRRK2-IN-1 and U0126 treatment on this target.

\section{Conclusions}

Although the overall function of DCLK1 and it's multiple isoforms and functional domains remains to be elucidated, our studies and others have implicated this protein as a key regulator of gut injury response and as a major regulator of proliferative, angiogenic, stemness, and EMT pathways in cancer. Taken together these findings support DCLK1's role as a broad regulator of the molecular and cellular mechanisms of tumorigenesis. Moreover, the restricted expression of DCLK1 in a limited set of normal cells and its upregulation and tumor-stem cell status in cancer tissue make it an ideal target for cancer therapy. The specificity of LRRK2-IN-1 for DCLK1 and the results of our studies support the development of DCLK1 kinase inhibitors against cancer. Given the recalcitrance of advanced gastrointestinal cancers in general, this therapeutic concept may have the potential to overcome limitations of current therapies which only target proliferating cells in the primary tumor, by repressing the EMT processes and stemness characteristics that fuel the fatal metastatic and drug resistant characteristics of advanced tumors.

\section{Methods}

\section{In vitro kinase assay}

Purified kinase-active DCLK1 (0.25 $\mu$ g, Signalchem) was incubated in kinase buffer II (Alfa Aesar) with $2.5 \mu \mathrm{g}$ of autocamtide II substrate (American Peptide Co.), $1 \mu \mathrm{M}$ ATP (Sigma), and either DMSO, 0.6, 1.25, 2.5, 5, 10, or $50 \mathrm{nM}$ LRRK2-IN-1 (Calbiochem) for $15 \mathrm{~min}$ at $30^{\circ} \mathrm{C}$. Subsequently, Kinase-Glo ${ }^{\circ}$ reagent (Promega) was added 1:1 to the reactions which were gently mixed and then incubated for another 15 minutes protected from light. Results were obtained using a Synergy HT plate reader (Biotek) capable of luminometric measurements.

\section{Molecular docking analysis}

The ligand structure for LRRK2-IN-1 was constructed in ChemDraw (CambridgeSoft ${ }^{\circ}$ ) and energy-minimized with UCSF Chimera [48]. Homology models of DCLK1 isoform 2 (DCLK-long- $\alpha$ ) and 4 (DCLK-long- $\beta$ ) were generated using Sparks ${ }^{\mathrm{X}}$ Fold Recognition software [49]. Docking analyses were carried out with PatchDock [50] and results were visualized with UCSF Chimera and LigPlot + [51]. Model predictions were checked for reasonable precision by repeating the modeling procedures using SwissModel [52].

\section{Cell culture}

AsPC-1, MiaPaCa-2, and SW1990 human pancreatic cancer cells, and HCT116, HT-29, and DLD-1 human colorectal cancer cells, were obtained from ATCC and grown in Dulbecco's Modified Eagle's Medium with $4.5 \mathrm{~g} / \mathrm{L}$ glucose and L-glutamine, without sodium pyruvate (Cellgro) supplemented with $10 \%$ fetal bovine serum (Sigma) at $37^{\circ} \mathrm{C}$ and $5 \% \mathrm{CO}_{2}$.

\section{Site-directed mutagenesis and lentiviral plasmid construction}

Human DCLK1 isoform short- $\alpha$ cDNA tagged with turboGFP (tGFP) (Origene) was used to create a kinase-dead mutant, in which the lysine at residue 419 was substituted with an arginine by site-directed mutagenesis using the QuickChange II mutagenesis kit (Agilent Technologies). The mutant construct was confirmed by DNA sequencing. Both wild-type DCLK1-tGFP and K419R-tGFP cDNAs were then amplified and ligated into pCR8-GW-TopoD (Invitrogen) following the manufacturer's protocol. Wildtype DCLK1-tGFP and K419R-tGFP cDNAs were then transferred to pLenti CMV PURO DEST empty (gift from Dr. Eric Campeau) using Clonase 2 (Invitrogen) following the manufacturer's recommendations.

\section{Generation of lentiviral particles and cell lines}

The expression plasmids constructed above were cotransfected along with packaging plasmids pMD2.G (Addgene), pMDL/RRE g/p (Addgene) and pRSV-Rev (Addgene) into $293 \mathrm{~T}$ cells. DNA was transfected into cells using the PEI transfection method with a PEI to DNA ratio of 1:1. Supernatants were harvested 48 and $72 \mathrm{~h}$ post-transfection and cleared through a $0.45 \mu \mathrm{m}$ filter. These viral supernatants were concentrated using polyethylene glycol 8000 (Sigma-Aldrich) as previously described [53] and cells were infected with concentrated virus and selected with puromycin (Sigma-Aldrich) to establish stable cell lines.

\section{Cell proliferation assays}

Cells $\left(10^{4}\right.$ cells per well) were seeded into a 96-well tissue culture plate in triplicate. The cells were cultured in the presence of LRRK2-IN-1 with DMSO as a vehicle at $0,0.31,0.63,1,2$, and 5,10 , and $20 \mu \mathrm{M} .48$ h post treatment, $10 \mu \mathrm{l}$ of TACS MTT Reagent (RND Systems) was added to each well and the cells were incubated at $37^{\circ} \mathrm{C}$ until dark crystalline precipitate became visible in the cells. $100 \mu \mathrm{l}$ of $266 \mathrm{mM} \mathrm{NH} \mathrm{NH}_{4} \mathrm{OH}$ in DMSO [54] was then added to the wells and placed on a plate shaker at low speed for 1 minute. After shaking, the plate was allowed to incubate for 10 minutes protected from light and the $\mathrm{OD}_{550}$ for each well was read using a microplate reader. The results were averaged and calculated as a 
percentage of the DMSO (vehicle) control +/- the standard error of the mean.

\section{Live-dead and Caspase 3/7 activity assays}

AsPC- 1 cells were seeded into a 96-well plate at $10^{4}$ cells per well and allowed to attach overnight at $37^{\circ} \mathrm{C}$. LRRK2-IN-1 was added to the wells at concentrations of 0 (DMSO), 0.3, 0.6, 1.25, 2.5, 5, 10, and $20 \mu \mathrm{M}$ in duplicate and incubated at $37^{\circ} \mathrm{C}$ for $24 \mathrm{~h}$. Fluorescent Live/Dead viability (Invitrogen) and luminescent CaspaseGlo ${ }^{\circ} 3 / 7$ activity (Promega) assays were performed according to the manufacturer's protocol.

\section{Flow cytometry}

To assess cell cycle status, AsPC- 1 cells were treated with LRRK2-IN-1 for 24 or $48 \mathrm{~h}$, trypsinized, centrifuged at $4^{\circ} \mathrm{C}$, washed with Automacs rinsing solution (Miltenyi), and then fixed in $70 \%$ ethanol on ice for 30 minutes. Following fixation the cells were washed with Automacs rinsing solution and incubated with propidium iodide $(50 \mu \mathrm{g} / \mathrm{ml})$ and treated with RNAse A. In another experiment to analyze the cycling status of smaller subpopulations of cells this process was repeated with longer fixation $(>2 \mathrm{~h}$ ) and the addition of $0.1 \%$ Triton-X 100 for permeabilization. Data was collected on FACS Calibur and analyzed in ModFit LT.

\section{Matrigel transwell invasion assays}

Control or matrigel coated transwells (BD Biosciences) were prepared by soaking in serum-free media for $2 \mathrm{~h}$ at $37^{\circ} \mathrm{C}$ in a 24-well plate. Subsequently, AsPC-1 cells (5000/well) were seeded into each transwell in serumfree media and treated with LRRK2-IN-1 or DMSO (vehicle) in duplicate. Cell culture medium containing $10 \%$ FBS was added to the bottom of each well as chemoattractant and the cells were incubated for $22 \mathrm{~h}$. Afterwards, a cotton swab was used to scrape non-invasive/ migratory cells off the top of transwells and the remaining cells were fixed with $100 \%$ methanol, stained with $1 \%$ toluidine blue/1\% borax, and allowed to dry. After drying, the film from the transwell inserts was removed with a scalpel blade and mounted on slides. For each sample 5 fields were counted at 10X magnification. Percent invasion was calculated by dividing the number of invading cells (matrigel-coated inserts) by the number of migrating cells (control inserts) and multiplying by 100 .

\section{Colony formation assay}

AsPC-1 cells (5000/well) overexpressing DCLK1, DCLK1K419R, or vector were seeded into $6 \mathrm{~cm}$ dishes in cell culture media containing 10\% FBS and either DMSO or LRRK2-IN-1 at 0.5 or $5 \mu \mathrm{M}$. The cells were allowed to grow for 9 days and then washed with PBS, fixed with glacial acetic acid/methanol solution (1:3), and washed with
PBS again. Colonies were stained with $0.5 \%$ crystal violet for 15 minutes and washed with tap water to remove excess stain. Colonies were then counted under a stereomicroscope using a $1 \mathrm{~cm}^{2}$ grid. Four squares from four quadrants were counted for each plate. The results were normalized to DMSO for each cell line in order to obtain the percent of colony formation. Stained colonies were then imaged, thresholded in ImageJ, and highlighted for visualization using the find edges ImageJ function.

\section{Wound healing assay}

$10^{5}$ AsPC-1 cells were seeded into 6-well plates and allowed to grow to confluence. A sterile $200 \mu \mathrm{l}$ pipette tip was used to scratch the confluent layer, and detached cells were removed with washing. For each plate 9 points were selected and marked and baseline images were taken at $4 \times$ magnification. Following baseline imaging drug or vehicle was added to each well. Images were again taken at 12, 24, 48, and $72 \mathrm{~h}$. The migrating edges were detected using the find edges function in ImageJ and images were converted to 16-bit format and thresholded. The empty region between migrating monolayer edges was selected and the area was measured using the measure tool. These values were used to perform standard calculations and migration over time was assessed by ANOVA.

\section{Quantitative real-time RT-PCR}

AsPC- 1 cells $\left(10^{5} /\right.$ well $)$ were seeded into 6-well plates in triplicate in the presence of LRRK2-IN-1 and incubated at $37^{\circ} \mathrm{C}$ for $8 \mathrm{~h}$. The cells were lysed, and total RNA was isolated using Tri Reagent (MRC) per the manufacturer's instructions. First strand cDNA synthesis was carried out using SuperScript II Reverse Transcriptase and random hexanucleotide primers (Invitrogen). The complementary DNA was subsequently used to perform RT-PCR on an iCycler IQ5 Thermal Cycler (BioRad) using SYBR Green (Molecular Probes) with gene-specific primers and JumpStart $^{\text {tux }}$ Taq DNA polymerase (Sigma). The crossing threshold value assessed was normalized to $\beta$-actin and quantitative changes in mRNA were expressed as foldchange relative to control \pm SEM value. The Student's $\mathrm{t}$-test was used to determine statistical significance. The primer sequences for the genes analyzed are provided in Additional file 1: Table S1.

\section{Generation of phospho-DCLK1 antibody}

A rabbit polyclonal antibody was commercially generated (Abbomax) to target ser-30( $\beta) / 336(\alpha)$, which has previously been demonstrated to be phosphorylated, against a 15 amino acid peptide sequence similar to others previously used to generate phospho-DCLK1 antibodies $[46,55]$. To confirm specificity, ELISA was performed using phosphospecific and non-phosphospecific peptide. 


\section{Western blotting}

Denatured proteins of cell lysates were subjected to Western blot analysis. The concentration of total proteins was determined by BCA protein assay (Pierce, Rockford, IL). $40 \mu \mathrm{g}$ of total proteins was separated on a $7.5 \%-15 \%$ SDS polyacrylamide gel and transferred onto a PVDF membrane. The membrane was blocked in 5\% non-fat dry milk for $1 \mathrm{~h}$ and probed overnight with primary antibody. Subsequently the membrane was incubated with infrared cw800-conjugated secondary antibody for $1 \mathrm{~h}$ at room temperature. The proteins were detected using a LICOR Odyssey Infrared Imager. Protein density quantification was performed in Image Studio Lite (LICOR). The antibodies used were $\alpha$-DCLK1 (ABCAM, AB31704), $\alpha$-phosphoDCLK1, $\alpha$-C-MYC (Santa Cruz, SC-40), $\alpha-$ BCL2 (Santa Cruz, SC-492), and $\alpha$-phosphohistone H3 (EMD-Millipore 07-492).

\section{Immunofluorescence}

Cells grown on glass coverslips and treated with DMSO or LRRK2-IN-1 were rinsed with PBS, fixed in formalin, rinsed again with PBS, and permeabilized with $0.1 \%$ Triton-X. Following permeabilization cells were incubated at $4^{\circ} \mathrm{C}$ overnight with $\alpha$-phosphohistone $\mathrm{H} 3 \mathrm{di}$ luted $1: 10000$ in $0.01 \%$ Triton-X containing 1\% BSA. After incubation, cells were washed with PBS, and secondary antibody (Alexa-Fluor 547) diluted 1:2000 in PBS was added and allowed to incubate for 30 minutes at room temperature. After washing with PBS the coverslips were counterstained with Hoechst 33342, rinsed with PBS and distilled water, mounted on slides using Prolong gold antifade reagent (Invitrogen), and imaged with a Nikon Eclipse Ti microscope.

\section{Xenograft tumor study}

AsPC-1 cells $\left(5 \times 10^{5}\right)$ were injected subcutaneously into the flanks of athymic nude mice and allowed to grow until the tumor reached an average volume of $100 \mathrm{~mm}^{3}$. LRRK2-IN-1 was solubilized in $20 \%$ Captisol $^{\odot}$ and the xenografts were injected peritumorally with either $20 \%$ Captisol (vehicle) or LRRK2-IN-1 (100 mg/kg). Injections were performed on Monday, Wednesday, and Friday for 4 weeks (a total of 12 injections). Horizontal and vertical tumor diameter was measured on each injection date with calipers and tumor volume was calculated using the formula: tumor volume $=0.5 \times$ length $\times$ width $^{2}$. At the end of the injection period mice were killed by $\mathrm{CO}_{2}$ asphyxiation and tumors were excised, weighed, and measured. All animal experiments were performed in accordance with standards set forth by the University of Oklahoma Health Sciences Center's Institutional Animal Care and Use Committee.

\section{Analysis of TCGA and NCBI GEO datasets}

To perform The Cancer Genome Atlas (TCGA) Colon Adenocarcinoma (COAD) dataset analysis, isoform specific RNA-seq results for all stages of colon adenocarcinoma were downloaded from the TCGA open-access server. A workflow in Knime (version 2.8.1) was used to identify and aggregate transcript data. NCBI gene expression omnibus (GEO) datasets were downloaded using NCBI's built in GEO2R analysis tool.

\section{Statistical analysis}

All statistical analyses were performed using Graphpad Prism 6.0 and Microsoft Excel. One-way ANOVA and the Student's T-test were used to determine statistical significance unless otherwise noted. For all analyses $\mathrm{p}<0.05$ was considered to be statistically significant.

\section{Additional file}

Additional file 1: Table S1. Primers sequence for genes analyzed by real-time RT-PCR. Figure S1. Cladogram of proteins closely related to DCLK1 as determined by Clustal $\Omega$ using the human kinome as input. Highlighting denotes solved structures (A) Anti- proliferative effect of LRRK2-IN-1 on colon and pancreatic cancer cell lines $48 \mathrm{~h}$ post-treatment (B). Figure S2. Two-dimensional plot of LRRK2-IN-1 and interacting residues as plotted by LigPlot and color-coded to agree with Figure $1 \mathrm{E}$ Red rays denote hydrophobic interactions and the green dashed line denotes 2.63A length hydrogen bonding between the ligand and Aspartate 226. Residue labeling agrees with the SwissProt entry for DCLK1 isoform 4 (A). Fluorescent images of cells stained with Calcein-AM (Live/Green) and Eth-D (Dead/Red) following LRRK2-IN-1 treatment (B). NCBI Geo data of DCLK1 gene expression in various pancreatic cancer cell lines compared to HPDE immortalized normal human pancreatic ductal epithelial cells (GSE40099) and comparison of DCLK1 gene expression in colon cancer cell lines from the $\mathrm{NCl-60}$ cell panel (GDS 1761) (C) Exponential plots demonstrating strong associations between cell death and caspase activity and percentage of G2/M arrest (D-E) NCBI Geo data of DCLK1 gene expression in colon cancer cell lines treated with $10 \mu \mathrm{M}$ of $\mathrm{U} 0126$ (F).

\section{Competing interests}

C.W. Houchen is a Co-Founder of COARE Biotechnology. The other authors disclose no potential conflicts of interest.

\section{Authors' contributions}

$\mathrm{NW}, \mathrm{DQ}, \mathrm{RM}$, and $\mathrm{CWH}$ conceived of the study, designed the experiments, interpreted the data, and drafted the manuscript. NW, DQ, RM, and DBO performed the in vitro, in vivo, and histological procedures, collected the data, and prepared the images for publication. WLB and RJ aided in experimental design, prepared lentivirus, generated stable cell lines, provided technical support, and proofread the manuscript. PC, SMS, and NA provided technical support and proofread the manuscript. All authors read and approved the final manuscript.

\section{Acknowledgements}

We would like to acknowledge Jim Henthorn and Scott Mitchell of the University of Oklahoma Health Sciences Center Flow Cytometry and Imaging Core for their assistance in FACS data collection and analysis.

\section{Author details}

${ }^{1}$ Department of Medicine, University of Oklahoma Health Sciences Center, Oklahoma City, OK, USA. ²Department of Veterans Affairs Medical Center, Oklahoma City, OK, USA. ${ }^{3}$ Peggy and Charles Stephenson Oklahoma Cancer 
Center, Oklahoma City, OK, USA. ${ }^{4}$ Department of Cell Biology, University of Oklahoma Health Sciences Center, Oklahoma City, OK, USA. ${ }^{5}$ COARE

Biotechnology, Oklahoma City, OK, USA.

Received: 10 January 2014 Accepted: 24 April 2014

Published: 6 May 2014

\section{References}

1. Gambacorti-Passerini C, Antolini L, Mahon FX, Guilhot F, Deininger M, Fava C, Nagler A, Della Casa CM, Morra E, Abruzzese E, D'Emilio A, Stagno F, le Coutre P, Hurtado-Monroy R, Santini V, Martino B, Pane F, Piccin A, Giraldo P, Assouline S, Durosinmi MA, Leeksma O, Pogliani EM, Puttini M, Jang E, Reiffers J, Valsecchi MG, Kim DW: Multicenter independent assessment of outcomes in chronic myeloid leukemia patients treated with imatinib. J Natl Cancer Inst 2011, 103:553-561.

2. Llovet JM, Ricci S, Mazzaferro V, Hilgard P, Gane E, Blanc JF, de Oliveira AC, Santoro A, Raoul JL, Forner A, Schwartz M, Porta C, Zeuzem S, Bolondi L, Greten TF, Galle PR, Seitz JF, Borbath I, Haussinger D, Giannaris T, Shan M, Moscovici M, Voliotis D, Bruix J, Sharp Investigators Study Group: Sorafenib in advanced hepatocellular carcinoma. N Engl J Med 2008, 359:378-390.

3. Mok TS, Wu YL, Thongprasert S, Yang CH, Chu DT, Saijo N, Sunpaweravong P, Han B, Margono B, Ichinose Y, Nishiwaki Y, Ohe Y, Yang JJ,

Chewaskulyong B, Jiang H, Duffield EL, Watkins CL, Armour AA, Fukuoka M: Gefitinib or carboplatin-paclitaxel in pulmonary adenocarcinoma. N Engl $J$ Med 2009, 361:947-957.

4. Zhang J, Yang PL, Gray NS: Targeting cancer with small molecule kinase inhibitors. Nat Rev Cancer 2009, 9:28-39.

5. May R, Riehl TE, Hunt C, Sureban SM, Anant S, Houchen CW: Identification of a novel putative gastrointestinal stem cell and adenoma stem cell marker, doublecortin and CaM kinase-like-1, following radiation injury and in adenomatous polyposis coli/multiple intestinal neoplasia mice. Stem Cells 2008, 26:630-637.

6. May R, Sureban SM, Lightfoot SA, Hoskins AB, Brackett DJ, Postier RG, Ramanujam R, Rao CV, Wyche JH, Anant S, Houchen CW: Identification of a novel putative pancreatic stem/progenitor cell marker DCAMKL-1 in normal mouse pancreas. Am J Physiol Gastrointest Liver Physiol 2010, 299:G303-G310.

7. Sureban SM, May R, Ramalingam S, Subramaniam D, Natarajan G, Anant S, Houchen CW: Selective blockade of DCAMKL-1 results in tumor growth arrest by a Let-7a MicroRNA-dependent mechanism. Gastroenterology 2009, 137:649-659. 659 e641-642.

8. Sureban SM, May R, Lightfoot SA, Hoskins AB, Lerner M, Brackett DJ, Postier RG, Ramanujam R, Mohammed A, Rao CV, Wyche JH, Anant S, Houchen CW: DCAMKL-1 regulates epithelial-mesenchymal transition in human pancreatic cells through a miR-200a-dependent mechanism. Cancer Res 2011, 71:2328-2338

9. Bailey JM, Alsina J, Rasheed ZA, McAllister FM, Fu YY, Plentz R, Zhang H, Pasricha PJ, Bardeesy N, Matsui W, Maitra A, Leach SD: DCLK1 marks a morphologically distinct subpopulation of cells with stem cell properties in pre-invasive pancreatic cancer. Gastroenterology 2013, 146:245-256.

10. Gerbe F, van Es JH, Makrini L, Brulin B, Mellitzer G, Robine S, Romagnolo B, Shroyer NF, Bourgaux JF, Pignodel C, Clevers H, Jay P: Distinct ATOH1 and Neurog3 requirements define tuft cells as a new secretory cell type in the intestinal epithelium. J Cell Biol 2011, 192:767-780.

11. Nakanishi Y, Seno H, Fukuoka A, Ueo T, Yamaga Y, Maruno T, Nakanishi N, Kanda K, Komekado H, Kawada M, Isomura A, Kawada K, Sakai Y, Yanagita M, Kageyama R, Kawaguchi Y, Taketo MM, Yonehara S, Chiba T: Dclk1 distinguishes between tumor and normal stem cells in the intestine. Nat Genet 2012, 45:98-103.

12. Verissimo CS, Molenaar JJ, Meerman J, Puigvert JC, Lamers F, Koster J, Danen $E H$, van de Water B, Versteeg R, Fitzsimons $C P$, Vreugdenhil E: Silencing of the microtubule-associated proteins doublecortin-like and doublecortin-like kinase-long induces apoptosis in neuroblastoma cells. Endocr Relat Cancer 2010, 17:399-414.

13. Verissimo CS, Elands R, Cheng S, Saaltink DJ, Ter Horst JP, Alme MN, Pont C, van de Water B, Havik B, Fitzsimons CP, Vreugdenhil E: Silencing of Doublecortin-Like (DCL) results in decreased mitochondrial activity and delayed neuroblastoma tumor growth. PLoS One 2013, 8:e75752.

14. Sureban SM, May R, Mondalek FG, Qu D, Ponnurangam S, Pantazis P Anant S, Ramanujam RP, Houchen CW: Nanoparticle-based delivery of siDCAMKL-1 increases microRNA-144 and inhibits colorectal cancer tumor growth via a Notch-1 dependent mechanism. J Nanobiotechnol 2011, 9:40

15. Sureban SM, May R, Qu D, Weygant N, Chandrakesan P, Ali N, Lightfoot SA Pantazis P, Rao CV, Postier RG, Houchen CW: DCLK1 Regulates Pluripotency and Angiogenic Factors via microRNA-Dependent Mechanisms in Pancreatic Cancer. PLoS One 2013, 8:e73940.

16. Liu GH, Qu J, Suzuki K, Nivet E, Li M, Montserrat N, Yi F, Xu X, Ruiz S, Zhang W, Wagner U, Kim A, Ren B, Li Y, Goebl A, Kim J, Soligalla RD, Dubova I, Thompson J, Yates J 3rd, Esteban CR, Sancho-Martinez I, Izpisua Belmonte JC: Progressive degeneration of human neural stem cells caused by pathogenic LRRK2. Nature 2012, 491:603-607.

17. Deng X, Dzamko N, Prescott A, Davies P, Liu Q, Yang Q, Lee JD, Patricelli MP, Nomanbhoy TK, Alessi DR, Gray NS: Characterization of a selective inhibitor of the Parkinson's disease kinase LRRK2. Nat Chem Biol 2011, 7:203-205.

18. Thu KL, Radulovich N, Becker-Santos DD, Pikor LA, Pusic A, Lockwood WW, Lam WL, Tsao MS: SOX15 is a candidate tumor suppressor in pancreatic cancer with a potential role in Wnt/beta-catenin signaling. Oncogene 2014, 33:279-288.

19. Ross DT, Scherf $U$, Eisen MB, Perou CM, Rees C, Spellman P, lyer $V$, Jeffrey SS, Van de Rijn M, Waltham M, Pergamenschikov A, Lee JC, Lashkari D, Shalon D, Myers TG, Weinstein JN, Botstein D, Brown PO: Systematic variation in gene expression patterns in human cancer cell lines. Nat Genet 2000, 24:227-235.

20. Kantara C, O'Connell M, Sarkar S, Moya S, Ullrich R, Singh P: Curcumin Promotes Autophagic Survival of a Sub-Set of Colon Cancer Stem Cells, which are Ablated by DCLK1-siRNA. Cancer Res 2014.

21. Ponnurangam S, Mammen JM, Ramalingam S, He Z, Zhang Y, Umar S, Subramaniam D, Anant S: Honokiol in combination with radiation targets notch signaling to inhibit colon cancer stem cells. Mol Cancer Ther 2012, 11:963-972.

22. Li L, Bellows CF: Doublecortin-like kinase 1 exhibits cancer stem cell-like characteristics in a human colon cancer cell line. Chin J Cancer Res 2013, 25:134-142.

23. Duesberg $P$, Stindl R, Hehlmann R: Origin of multidrug resistance in cells with and without multidrug resistance genes: chromosome reassortments catalyzed by aneuploidy. Proc Natl Acad Sci U S A 2001, 98:11283-11288.

24. Nishimoto S, Nishida E: MAPK signalling: ERK5 versus ERK1/2. EMBO Rep 2006, 7:782-786

25. Watanabe K, Akimoto Y, Yugi K, Uda S, Chung J, Nakamuta S, Kaibuchi K, Kuroda $S$ : Latent process genes for cell differentiation are common decoders of neurite extension length. J Cell Sci 2012, 125:2198-2211.

26. Leushacke M, Sporle R, Bernemann C, Brouwer-Lehmitz A, Fritzmann J, Theis M, Buchholz F, Herrmann BG, Morkel M: An RNA interference phenotypic screen identifies a role for FGF signals in colon cancer progression. PLoS One 2011, 6:e23381.

27. Jurchott K, Kuban RJ, Krech T, Bluthgen N, Stein U, Walther W, Friese C, Kielbasa SM, Ungethum U, Lund P, Knosel T, Kemmner W, Morkel M, Fritzmann J, Schlag PM, Birchmeier W, Krueger T, Sperling S, Sers C, Royer $H D$, Herzel $H$, Schafer R: Identification of Y-box binding protein 1 as a core regulator of MEK/ERK pathway-dependent gene signatures in colorectal cancer cells. PLoS Genet 2010, 6:e1001231.

28. Itzkovitz S, Lyubimova A, Blat IC, Maynard M, van Es J, Lees J, Jacks T, Clevers $H$, van Oudenaarden A: Single-molecule transcript counting of stem-cell markers in the mouse intestine. Nat Cell Biol 2012, 14:106-114.

29. Van Landeghem L, Santoro MA, Krebs AE, Mah AT, Dehmer JJ, Gracz AD, Scull BP, McNaughton K, Magness ST, Lund PK: Activation of two distinct Sox9-EGFP-expressing intestinal stem cell populations during crypt regeneration after irradiation. Am J Physiol Gastrointest Liver Physiol 2012, 302:G1111-G1132

30. May R, Qu D, Weygant N, Chandrakesan P, Ali N, Lightfoot SA, Li L, Sureban SM, Houchen CW: Dclk1 deletion in tuft cells results in impaired epithelial repair after radiation injury. Stem Cells 2013.

31. Schepers $A G$, Snippert $H J$, Stange $D E$, van den Born $M$, van Es JH, van de Wetering $M$, Clevers $\mathrm{H}$ : Lineage tracing reveals Lgr5+ stem cell activity in mouse intestinal adenomas. Science 2012, 337:730-735.

32. Proctor E, Waghray M, Lee CJ, Heidt DG, Yalamanchili M, Li C, Bednar F, Simeone DM: Bmi1 enhances tumorigenicity and cancer stem cell function in pancreatic adenocarcinoma. PLoS One 2013, 8:e55820.

33. Ying H, Kimmelman AC, Lyssiotis CA, Hua S, Chu GC, Fletcher-Sananikone E, Locasale JW, Son J, Zhang H, Coloff JL, Yan H, Wang W, Chen S, Viale A, 
Zheng H, Paik JH, Lim C, Guimaraes AR, Martin ES, Chang J, Hezel AF, Perry SR, Hu J, Gan B, Xiao Y, Asara JM, Weissleder R, Wang YA, Chin L, Cantley LC, DePinho RA: Oncogenic Kras maintains pancreatic tumors through regulation of anabolic glucose metabolism. Cell 2012, 149:656-670.

34. Phipps Al, Buchanan DD, Makar KW, Win AK, Baron JA, Lindor NM, Potter JD, Newcomb PA: KRAS-mutation status in relation to colorectal cancer survival: the joint impact of correlated tumour markers. Br J Cancer 2013, 108:1757-1764

35. Rhim AD, Mirek ET, Aiello NM, Maitra A, Bailey JM, McAllister F, Reichert M, Beatty GL, Rustgi AK, Vonderheide RH, Leach SD, Stanger BZ: EMT and dissemination precede pancreatic tumor formation. Cell 2012, 148:349-361.

36. Chaffer $C L$, Weinberg RA: A perspective on cancer cell metastasis. Science 2011, 331:1559-1564.

37. Valenta T, Hausmann G, Basler $\mathrm{K}$ : The many faces and functions of beta-catenin. EMBO J 2012, 31:2714-2736.

38. Sanchez-Tillo E, de Barrios O, Siles L, Cuatrecasas M, Castells A, Postigo A beta-catenin/TCF4 complex induces the epithelial-to-mesenchymal transition (EMT)-activator ZEB1 to regulate tumor invasiveness. Proc Natl Acad Sci U S A 2011, 108:19204-19209.

39. Cancer Genome Atlas N: Comprehensive molecular characterization of human colon and rectal cancer. Nature 2012, 487:330-337.

40. Shimomura $S$, Nagamine $T$, Nimura $T$, Sueyoshi $N$, Shigeri $Y$, Kameshita I: Expression, characterization, and gene knockdown of zebrafish doublecortin-like protein kinase. Arch Biochem Biophys 2007, 463:218-230.

41. Lin PT, Gleeson JG, Corbo JC, Flanagan L, Walsh CA: DCAMKL1 encodes a protein kinase with homology to doublecortin that regulates microtubule polymerization. J Neurosci 2000, 20:9152-9161.

42. Nagamine T, Shimomura S, Sueyoshi N, Kameshita I: Influence of Ser/Pro-rich domain and kinase domain of double cortin-like protein kinase on microtubule-binding activity. J Biochem 2011, 149:619-627.

43. Davis MI, Hunt JP, Herrgard S, Ciceri P, Wodicka LM, Pallares G, Hocker M, Treiber DK, Zarrinkar PP: Comprehensive analysis of kinase inhibitor selectivity. Nat Biotechnol 2011, 29:1046-1051.

44. Wacker SA, Houghtaling BR, Elemento O, Kapoor TM: Using transcriptome sequencing to identify mechanisms of drug action and resistance. Nat Chem Biol 2012, 8:235-237.

45. Dhillon AS, Hagan S, Rath O, Kolch W: MAP kinase signalling pathways in cancer. Oncogene 2007, 26:3279-3290.

46. Kuribara M, Jenks BG, Dijkmans TF, de Gouw D, Ouwens DT, Roubos EW Vreugdenhil E, Scheenen WJ: ERK-regulated double cortin-like kinase (DCLK)-short phosphorylation and nuclear translocation stimulate POMC gene expression in endocrine melanotrope cells. Endocrinology 2011, 152:2321-2329.

47. Miyamoto-Sato E, Fujimori S, Ishizaka M, Hirai N, Masuoka K, Saito R, Ozawa Y, Hino K, Washio T, Tomita M, Yamashita T, Oshikubo T, Akasaka H, Sugiyama J, Matsumoto $\mathrm{Y}$, Yanagawa $\mathrm{H}$ : A comprehensive resource of interacting protein regions for refining human transcription factor networks. PLOS One 2010, 5:e9289.

48. Pettersen EF, Goddard TD, Huang CC, Couch GS, Greenblatt DM, Meng EC, Ferrin TE: UCSF Chimera-a visualization system for exploratory research and analysis. J Comput Chem 2004, 25:1605-1612.

49. Yang $Y$, Faraggi $E$, Zhao $H$, Zhou $Y$ : Improving protein fold recognition and template-based modeling by employing probabilistic-based matching between predicted one-dimensional structural properties of query and corresponding native properties of templates. Bioinformatics 2011, 27:2076-2082

50. Schneidman-Duhovny D, Inbar Y, Polak V, Shatsky M, Halperin I, Benyamini H, Barzilai A, Dror O, Haspel N, Nussinov R, Wolfson HJ: Taking geometry to its edge: fast unbound rigid (and hinge-bent) docking. Proteins 2003, 52:107-112.

51. Laskowski RA, Swindells MB: LigPlot+: multiple ligand-protein interaction diagrams for drug discovery. J Chem Inf Model 2011, 51:2778-2786.

52. Schwede T, Kopp J, Guex N, Peitsch MC: SWISS-MODEL: An automated protein homology-modeling server. Nucleic Acids Res 2003, 31:3381-3385.

53. Chang L-J, Zaiss A-K: Lentiviral vectors preparation and use. In Gene Therapy Protocols, Volume 69. Edited by Morgan J. New York: Springer; 2002:303-318. Methods in Molecular Medicine.
54. Wang $H$, Wang $F$, Tao $X$, Cheng $H$ : Ammonia-containing dimethyl sulfoxide: an improved solvent for the dissolution of formazan crystals in the 3-(4,5-dimethylthiazol-2-yl)-2,5-diphenyl tetrazolium bromide (MTT) assay. Anal Biochem 2012, 421:324-326.

55. Rouwette TP, Kozicz T, Olde Loohuis NF, Gaszner B, Vreugdenhil E, Scheffer GJ, Roubos EW, Vissers KC, Scheenen WJ: Acute pain increases phosphorylation of DCLK-long in the Edinger-Westphal nucleus but not in the hypothalamic paraventricular nucleus of the rat. J Pain 2010, 11:930-940.

doi:10.1186/1476-4598-13-103

Cite this article as: Weygant et al.: Small molecule kinase inhibitor LRRK2-IN-1 demonstrates potent activity against colorectal and pancreatic cancer through inhibition of doublecortin-like kinase 1. Molecular Cancer 2014 13:103.

\section{Submit your next manuscript to BioMed Central and take full advantage of:}

- Convenient online submission

- Thorough peer review

- No space constraints or color figure charges

- Immediate publication on acceptance

- Inclusion in PubMed, CAS, Scopus and Google Scholar

- Research which is freely available for redistribution 